\title{
Enhancing the Professional Growth of the Newly Qualified and Employed Teachers in Owerri Educational Zone Through the Use of Teacher Mentoring
}

\author{
Duru Veronica Ngozi \\ Department of Life Science Education \\ Imo State University
}

\begin{abstract}
This work studied the effect of teacher mentoring on the professional growth of newly qualified and employed teachers (NQETs) in Owerri educational zone I. The researcher adopted descriptive survey and pre-test, post test, control group designs. Simple random sampling and purposive sampling technique were used to select 20 NQETs, 10 experienced basic science teachers and 80 basic science students. The instruments used for data collection were; Researcher-structured checklist with observational rating scale on teachers' knowledge of subject matter which was validated with reliability coefficient of 0.70 and the second instrument, classroom teaching competences and reflective ability questionnaire which was adopted and used. The third instrument was the Basic Science Achievement Test (BSAT) administered to students in both groups as post test. With the three instruments data were collected by observing the mentored teachers in classroom, while teaching students were post-tested. Data collected were analyzed, mean score and standard deviations were used to answer the research questions while the hypotheses were tested at 0.05 levels of significance. The findings of the study among others are; (1) That teachermentoring of NQETs enhanced teachers' knowledge of subject matter, (2) That teacher-mentoring enhances professional competences and reflective abilities of NQETs. (3) Students taught by mentored teachers performed better than students taught by non - mentored teachers. Based on the findings, the researcher made some recommendations among which are:(1) that teacher training institutions should adopt teacher-mentoring to improve teachers knowledge of subject matter, professional competences and reflective abilities (2) that the State School Management Board (SEMB) and State Universal Education Board, should organize orientation on appropriate strategies of teacher mentoring for more experienced serving teachers (3) New qualified and employed teachers (NQTRs) should be assigned to teacher mentors of the same professional status (in the same institution) who will give them support and guidance required on their new profession.
\end{abstract}

\section{Introduction}

The teacher occupies a central position in the process of curriculum development, implementation, and innovation [2]. It has always been said that the proper implementation of any curriculum depends on the quality of the teachers. In this regard, the need to continuously update the knowledge and support the professional development of serving and newly qualified teachers (NQTs) remains paramount in educational planning.

In our own context in Nigeria, it has been noted that there are several reasons why we need to continuously update the knowledge and enhance the development of reflective ability of the serving teachers and newly qualified and employed teachers (NQETs). Among these reasons are; first, the proper implementation of any curriculum depends on the quality of the teachers. Secondly, there is a common adage that says, "No nation can rise above the level of its educational system". The implication of this to national building is that the federal and state government should continue to give quality teachers education adequate attention it deserves.

In realization of this, the federal government through its agencies has made several efforts to enhance the quality of teachers in her educational system by organizing several teacher-retraining programmes for serving teachers in both primary and secondary schools in Nigeria educational system. These teacher retraining programs are geared towards development of teachers' professional skills and competences, and helping them to be aware of their professional practices. Lindgren stated that awareness of professional practice usually influence their attitudes and opinions about the teachers' role and school work [6]. Duru gave examples of these teacher professional development programs as follows [2]:

(1) Re-training program for teachers in six consecutive years organized by Universal Basic Education Commission (UBEC) in response to Millennium Development Goal Initiative on Education.

(2) The teacher re-training program organized by National Teachers Institute (NTI) in collaboration with state Universal Basic Education Board (SUBEB), etc. These programs are meant to enhance teachers' professional practices and knowledge of subject matter. 
The crux of the matter can be explained as follows:

First, these re-training programmes were not situated in context and in a close guidance of a more knowledgeable and experienced teacher on one to one basis.

Secondly, the trainers were not in the same professional status.

Lastly, it is usually done under "a hurry-up" approach of not more than two weeks. With this approach, newly qualified and employed teachers are not well grounded in their knowledge of subject matter and some professional practices such as self confidence and reflective ability. It is against this background that the researcher has pin-pointed teacher mentoring as a more preferable way of retraining serving and newly qualified and employed teachers (NQETs).

In teacher mentoring, NQETs are attached to different teachers who are more experienced and more knowledgeable and on the same professional status. This method of re-training teachers is referred to as "teacher mentoring". Lindgren contends that teacher mentoring which is well planned, with well stated goals and well trained mentors enables newly employed teachers to develop sound teaching practices and attain self awareness through constructive criticism in mentoring process [6]. Again, Pollard argued that mentoring helps teachers to acquire professional skills and competences faster and the knowledge of subject matter acquired in this way is better retained because the communication is face to face and on one to one, in a sustained period of time [7]. Lindgren further explained that in good teacher mentoring learning is situated in a contextual environment [6]. It is also believed that students taught by mentored teachers will learn faster and perform better in achievement test than those taught by non - mentored teachers.

Avarado stated that in this approach of re-training teachers, the mentor is not appointed from higher institution to come and lecture on some teaching pedagogies, rather it is more of learning by coaching, modeling and observation [1]. It is based on this back ground that the researcher has undertaken the present study which is "Enhancing the professional growth of newly qualified and employed teachers (NQETs) in Owerri Educational Zone.

\section{Conceptual Framework}

Teacher mentoring can be described as a process whereby a more experienced teacher facilitate or provides guidance to the newly qualified and employed teachers in the process of preparing the lesson plans, delivery, selection of teaching methods, development and utilization of instructural materials and mode of obtaining feed back from the students. Ingersoll and Kralik explained teacher mentoring as professional support, guidance and orientation programmes given to beginning teachers of primary and secondary schools during the transition in their first teaching job [4]. He called it induction. Lindgren described teacher mentoring as guidance by old and more experienced teachers to new teachers through the transition from being a student to becoming a teacher by offering them opportunity to share their own knowledge and experiences [5]. Ingersoll stated that the overall objective of teacher mentoring is to provide new comers with local guide on professional practices and reflective ability [4]. Professional practices ranges from all the teacher need to know in his/her subject matter to the skills and competences he/she requires to apply in classroom teaching such as planning the lesson, delivery of lesson, selection and use of teaching methods and instructional materials, classroom management, evaluation procedures, teacher-pupil relationships, etc.

On the other hand, reflective ability involves ability of the teacher to carry out self-appraisal over what he has taught in order to eliminate undue autonomy in pursuing the predetermined educational objectives, Pollard [7]. Reflective teaching could also be explained as a way a teacher deliberates or cogitates on what he or she has taught to ensure that he is on the right track with regard to official scheme of work and right professional practices.

Again, when newly qualified teacher has moved from a state of novice teacher to the level of teacher with self awareness of basic professional practices and reflective ability, he/she has attained professional growth.

Pollard explained teacher mentoring as one fast reliable mode of professionalizing teaching and providing teachers who are knowledgeable and current in modern art of teaching [7].

\section{Statement of the Problem}

It has been observed that some newly qualified and employed teachers in government owned and private secondary schools need to be provided with continuous professional development and support in order to bring them to acceptable standard. Consequently they need to be placed under the guidance of more experienced and exceptional teachers who will supervise, monitor and provide academic support.

In the same way, the old serving teachers who do not have the opportunity of attending any refresher courses need teacher mentoring to assist and expose them to varieties of innovation in education. Studies have shown that teacher mentoring is one mode of professionalizing teaching and providing teachers who are knowledgeable and current in modern art of teaching. Examples of such studies are Pollard, Lindgren, Furlong, etc [3] [5] [7]. 
These studies were not carried out in Nigeria. The researcher is therefore poised to investigate the effect of teacher mentoring on the professional development of newly qualified and employed teachers particularly on their knowledge of subject matter and reflective ability. These if improved, has positive effects on students learning.

The problem of this study can be stated thus: what is the effect of teacher mentoring on teachers' knowledge of subject matter? Can teacher mentoring enhance the reflective ability of the basic science teachers? This study is therefore designed to find out if mentoring can enhance teachers' knowledge of subject matter and enhance the development of reflective ability of basic science teachers. Can students taught by mentored teachers perform better in assessment test than their counterparts?

\section{Purpose of Study}

The main purpose of this study is to determine the effect of mentoring on teachers' knowledge of subject matter. The second purpose of the study is to ascertain whether mentoring can enhance the development of reflective ability and some classroom competences of the basic science teachers and also improve students’ performance.

\section{Research Questions}

The researcher posed two research questions to guide the study:

1. What is the difference in the mean performance of newly qualified teachers who were mentored and those who were not mentored in their knowledge of subject matter?

2. What is the difference in the mean score performance of newly qualified and employed teachers who were mentored and those who were not mentored in their reflective ability and classroom competences?

3. What is the difference in mean score performance of students taught by mentored teachers and those taught by non - mentored teachers?

\section{Null Hypothesis}

The researcher formulated two null hypotheses to guide the study.

1. There is no significant difference $(\mathrm{P}<0.05)$ in the mean score performance of teachers who were mentored and those who were not mentored in their knowledge of subject matter.

2. There is no significant difference $(P<0.05)$ in the mean score performance of teachers who were mentored and those who were not mentored in their development of reflective abilities and classroom competences.

3. There is no significant difference $(P<0.05)$ in the mean score performance of students taught by mentored teachers and those taught by non mentored teachers.

\section{Research Design and Procedure}

The research design adopted for this study was pretest-post test control group design and also descriptive survey design. In this design, the newly employed teachers were randomly assigned into experimental and control groups. Basic science students in two intact classes were assigned to group $\mathrm{A}$ and $\mathrm{B}$ respectively. Both groups were pre-tested (observed) using the two instruments respectively. At the end of the treatment on experimental group, both groups were post-tested (observed in the class) using the same instruments (checklists with observational rating scale). In both the pretest and post-test, teachers were observed and scored individually using the checklist with rating scale. Students were posttested using the third instrument (BSAT).

\section{Population of the Study}

A population of one thousand Basic Science students in junior secondary two (JSS2), and sixty basic science teachers from the five junior secondary schools in Owerri municipal L.G.A. in the year 2013 was used for the research. The population was therefore, 1060 (one thousand and sixty subjects).

\section{Sample and Sampling Technique}

Simple random sampling technique was used to select 250 students, 50 students from each school. These 50 students were randomly assigned to two groups; A \& B. For the teachers, purposive sampling technique was used to select all the newly employed teachers who have not worked up to one year in their respective schools. Simple random sampling technique was used to select four teachers from each school making up a total of twenty newly qualified and employed teachers. For the teacher mentors first purposive sampling technique was used to select all the teachers who have worked up to ten years and above, from the number ten teachers who are more experienced were selected based on the information obtained from them in an oral interview. In the interview they were asked about their years of experience, their interest and predisposition to serve as mentors and to attend the training programme. The twenty newly qualified and employed teachers 
were assigned into two groups; experimental group (A) and control group (B) respectively.

The ten more experienced teachers served as mentors to teachers in group A while teachers in group B were not mentored. Total sample used for the study was 280 subjects. Students in two intact classes were assigned to group A and B respectively.

\section{Instrument for Data Collection}

Three instruments were used for this study, (1) the observational rating scale on teachers knowledge of subject matter (ORTKSM), which was used to observe the teacher in the classroom on their knowledge of subject matter. (2) The classroom teaching competences questionnaire which was used to assess the teachers' reflective ability on some classroom teaching competences (CTCQ). (3) The basic science achievement test (BSAT) which was used as post - test for students.

The first instrument (ORSTKSM) was used in the pretest (observing teachers teaching) for both groups before exposing the experimental group to mentoring. The second instrument was given to both groups separately after the treatment on experimental group. The first instrument observational rating scale on teachers' knowledge of subject matter (ORSTKSM) comprised 12 items with rating 1- 5. The rating is as follows 1 (poor) 2 (fair) 3 (good) 4 (very good) 5 (excellent). The instrument was structured by the researcher to determine the extent of teachers' knowledge of subject matter. The second instrument was structured questionnaire known as classroom teaching competences questionnaire (CTCQ) which was used to assess teachers' reflective ability on some of the classroom competences, (TRACC). It was structured to elicit responses with weight attached as follows: strongly agreed $(\mathrm{SA})=4$, Agreed $(\mathrm{A})=3$, Disagreed $(\mathrm{DA})=$ 2 , Strongly Disagreed $(\mathrm{SDA})=1$. The third was (BSAT) which was adopted and used.

\section{Validation of Instrument}

The first instrument ORSTKSM was given to experts in measurement and evaluation to read through for face and content validity. They read through and made some corrections which the researcher effected before producing the final draft thus validity was ensured. The second instrument CTCQ was not subjected to any other screening because it has been validated and used in the assessment of teachers in the workshop organized for retraining of teachers by Universal Basic Education Commission (2013). The third was selected from JSE examination which has already been validated.

\section{Reliability of Instrument}

The first instrument ORSTKSM was used to observe teachers who were not listed for this study in their classroom teaching. After two weeks interval, the same instrument was administered on the same subjects. The two sets of scores were co-related using Cronbach's co-efficient formular. The coefficient obtained was 0.70 which indicated that the instrument is reliable. The second instrument, ORSTDSC has already been validated and therefore was adopted and used for the study. The third also has already been validated and was adopted and as such used.

\section{Administration of Instrument}

Before the mentoring programme started, both groups of teachers were observed in classrooms teaching, using the first instrument at different times to determine their knowledge of subject matter on the three topics selected for the study. After the mentoring programme, both the mentored and nonmentored teachers were made to teach their group of students the three topics selected from basic science for the study. The researcher observed the teachers teaching in their respective schools using the first instrument. The second instrument which was used to assess the reflective ability of the teachers on some of the classroom competences were given to them individually to complete. Data collected were analyzed and presented in tables. Students in both groups were given post - test.

\section{Method of Data Analysis}

The three research questions were answered using mean scores and standard deviations while the three null hypotheses were tested at 0.05 level of significance using t-test. The decision rule for researcher question 1 is 3.0 and above for positive result while decision for research question two is 2.50 and above for positive result.

\section{Data Analysis and Presentation of Results}

Research question I: What is the difference in mean score performance of newly qualified and employed teachers who were mentored and those who were not mentored in the development of knowledge of subject matter? 
Table 1. Mean score and standard deviations of NQETs who were mentored and those who were not mentored on the development of knowledge of subject matter

\begin{tabular}{|c|c|c|c|c|c|}
\hline & \multirow[t]{2}{*}{ Classroom observation } & \multicolumn{2}{|c|}{$\begin{array}{l}\text { Mentored } \\
\text { teachers }\end{array}$} & \multicolumn{2}{|c|}{$\begin{array}{l}\text { Non- } \\
\text { mentored } \\
\text { teachers }\end{array}$} \\
\hline & & $\bar{X}$ & SD & $\bar{X}$ & SD \\
\hline 1 & $\begin{array}{l}\text { States behavioural objectives in } \\
\text { simple and clear language }\end{array}$ & 3.9 & 0.7 & 1.8 & 0.53 \\
\hline 2 & 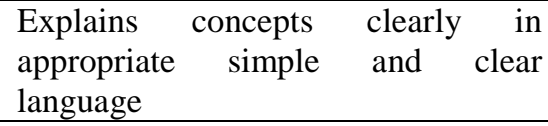 & 4.3 & 0.6 & 2.3 & 0.78 \\
\hline 3 & $\begin{array}{l}\text { Use of appropriate and familiar } \\
\text { examples to illustrate main concepts }\end{array}$ & 4.2 & 0.74 & 2.0 & 0.4 \\
\hline 4 & $\begin{array}{l}\text { Explains and elaborates main } \\
\text { concepts }\end{array}$ & 4.2 & 0.6 & 1.9 & 0.53 \\
\hline 5 & $\begin{array}{l}\text { Provides activities and opportunities } \\
\text { that help to develop process skills, } \\
\text { observation, manipulation, weighing } \\
\text { and measuring. }\end{array}$ & 3.9 & 0.53 & 2.0 & 0.44 \\
\hline 6 & Links activity to main concept & 4.2 & 0.75 & 2.2 & 0.4 \\
\hline 7 & $\begin{array}{l}\text { Guide learners to summarize main } \\
\text { points of lesson, through careful } \\
\text { structured questions }\end{array}$ & 4.2 & 0.75 & 2.2 & 0.4 \\
\hline 8 & $\begin{array}{l}\text { Materials and teachers demonstration } \\
\text { are appropriate for the purpose }\end{array}$ & 4.3 & 0.64 & 1.7 & 0.53 \\
\hline 9 & $\begin{array}{l}\text { Improvises and uses good and } \\
\text { relevant instructional material to } \\
\text { enhance students' understanding }\end{array}$ & 4.1 & 0.54 & 2.3 & 0.66 \\
\hline 10 & $\begin{array}{l}\text { Teacher relates pupils' idea to the } \\
\text { content being taught }\end{array}$ & 4.2 & 0.4 & 2.0 & 0.4 \\
\hline 11 & $\begin{array}{l}\text { Teacher discuses and corrects } \\
\text { students' misconceptions }\end{array}$ & 4.3 & 0.74 & 2.1 & 0.46 \\
\hline 12 & $\begin{array}{l}\text { Teachers' questions for formative } \\
\text { evaluation reflects the stated } \\
\text { behavioral objectives }\end{array}$ & 4.1 & 0.64 & 1.8 & 0.53 \\
\hline & Cluster mean & 49.8 & 7.49 & 24.3 & 5.5 \\
\hline
\end{tabular}

The result of data analysis on table I shows that the mean scores of all the items on the knowledge of subject matter by teachers who were mentored are greater than 3.0 used as the minimum mean rating for positive result (mean range $=3.9-$ 4.3). This implies that teachers who were exposed to mentoring improved on the knowledge of subject matter. On the other hand, the result of data analysis show that the mean scores of all the items on knowledge of subject matter by teachers who were not mentored are less than 3.0 used as minimum mean rating for positive result (mean range 1.8 - 2.3). This implies that teachers who were not mentored had poor knowledge of the subject matter which they taught students in the control group.

Research question 2: What is the difference in the mean score performance of newly qualified and employed teachers who were mentored and those who were not mentored in their reflective ability on selected classroom competences.

Table 2. Mean scores and standard deviations on responses of NQETs who were mentored and those who were not mentored on reflective ability on selected classroom competences

\begin{tabular}{|l|l|l|l|l|l|}
\hline S/no & Reflective activities (self assessment) & \multicolumn{2}{l}{ Mentored teachers } & \multicolumn{2}{l}{$\begin{array}{l}\text { Non-mentored } \\
\text { teachers }\end{array}$} \\
\cline { 3 - 6 } & & & & \\
\\
\cline { 3 - 6 } & & $\bar{X}$ & SD & $\bar{X}$ & SD \\
\hline 1 & Task setting & 4.1 & 0.54 & 1.8 & 0.6 \\
\hline 2 & Explaining & 4.0 & 0.45 & 1.4 & 0.5 \\
\hline 3 & $\begin{array}{l}\text { Scaffolding children's knowledge and } \\
\text { understanding }\end{array}$ & 4.3 & 0.46 & 1.6 & 0.6 \\
\hline 4 & Unit knowledge & 4.1 & 0.54 & 1.8 & 0.4 \\
\hline 5 & Diagnosing & 4.3 & 0.65 & 1.3 & 0.46 \\
\hline 6 & Questioning & 4.6 & 0.5 & 1.8 & 0.4 \\
\hline 7 & Giving feedback & 4.4 & 0.5 & 1.5 & 0.68 \\
\hline 8 & Classroom management & 4.3 & 0.46 & 1.4 & 0.5 \\
\hline & Cluster mean & 38.3 & 4.5 & 14.2 & 4.86 \\
\hline
\end{tabular}


The results of data analysis on table 2 shows that the mean scores of all the items on reflective activities on the part of the mentored teachers are greater than 2.50 used as minimum mean rating for positive responses (mean range $=4.0-4.6$ ). This implies that the mentored teachers have professionally improved on the selected classroom competences which they assessed themselves through reflective activities. On the other hand, the result of data analysis shows that the mean score of all the items on the part of the non-mentored teachers are less than 2.50 used as the minimum mean rating for positive responses (mean range $=1.3-1.8$ ). This implies that non-mentored teachers are professionally not developed on the selected classroom competences which they assessed themselves through reflective activities. The mean performance of mentored teachers is greater by 14.1.

Research question 3: What is the difference in the mean score performance of students taught by mentored teachers and those taught by non mentored teachers?

Table 3. Mean score and standard deviation of the two groups of students on Basic Science Achievement Test

\begin{tabular}{|l|l|l|l|l|}
\hline Groups & No & $\mathrm{X}$ & $\mathrm{SD}$ & $\mathrm{X}_{1^{-}} \mathrm{X}_{2}$ \\
\cline { 1 - 4 } $\begin{array}{l}\text { Experimental } \\
\text { Group }\end{array}$ & 25 & 67.08 & 3.67 & 11.88 \\
\cline { 1 - 1 } $\begin{array}{l}\text { Control } \\
\text { Group }\end{array}$ & 25 & 55.2 & 2.12 & \\
\hline
\end{tabular}

Data on table three revealed that the mean score of students taught by mentored teachers are greater than those taught by non-mentored teachers ( 67.08 > 55.21)

Hypothesis I: There is no significant difference in the mean score performance of teachers who were mentored and those who were not mentored in their knowledge of subject matter.

Table 4. t-test of no significant difference between mean score performance of mentored and nonmentored teachers on their knowledge of subject matter (KSM)

\begin{tabular}{|l|l|l|l|l|l|l|l|}
\hline $\begin{array}{l}\text { Vari- } \\
\text { ables }\end{array}$ & $\overline{\mathrm{X}}$ & $\mathrm{SD}$ & $\mathrm{N}$ & $\mathrm{DF}$ & $\mathrm{t}$-cal & $\mathrm{t}$-cri & Deci \\
\hline & & & & & & & 0.05 \\
\hline MTs & 49.8 & 7.99 & 10 & 18 & 8.68 & 2.101 & \\
\hline NMTs & 24.3 & 5.5 & 10 & & & & \\
\hline
\end{tabular}

The data analysis on table 4 above revealed that the calculated t-value (8.68) is greater than the critical t-value (2.101) at 0.05 level of significance. It implies that there is significant difference in the mean performance of mentored teachers (MTs) and non mentored teachers (NMTs). Therefore the null hypothesis of no significant difference was rejected for the alternative hypothesis of significant difference.

Hypothesis 2: There is no significant difference in the mean score performance of teachers who were mentored and those who were not mentored in their development of reflective ability.

Table 5. t-test analysis of non-significant difference between the mean score performance of teachers who were mentored and those who were not

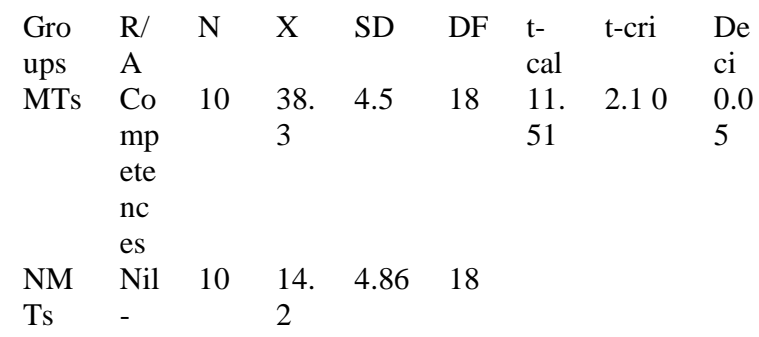

Data analysis on table 5 above revealed that the calculated t-value (11.51) is greater than the table tvalue (2.10) at 0.05 level of significance. It implies that there is a significant difference in the mean performance of mentored and non-mentored teachers. Therefore the null hypothesis of no significant difference was rejected for the alternative hypothesis.

Hypothesis 3:There is no significant difference between the mean score performance of students taught by mentored teachers and those taught by non - mentored teachers.

Table 6. t-test of no significant difference between the mean score performance of students taught by mentored teachers and those taught by nonmentored teachers

\begin{tabular}{|l|l|l|l|l|l|l|l|}
\hline $\begin{array}{l}\text { Varia } \\
\text { bles }\end{array}$ & $\overline{\mathrm{X}}$ & $\mathrm{SD}$ & $\mathrm{N}$ & $\begin{array}{l}\mathrm{D} \\
\mathrm{F}\end{array}$ & $\mathrm{t}$-cal & $\mathrm{t}$-cri & Deci \\
\hline SMTs & 67.08 & 3.67 & 25 & & & & \\
\hline $\begin{array}{l}\text { SNM } \\
\text { Ts }\end{array}$ & 55.2 & 2.12 & 25 & & & & \\
\hline
\end{tabular}

Data analysis on table six revealed that the calculated t-value (13.81) is greater than the critical 
t-value (1.67) at 0.05 level of significant. It implies that there is a significant difference in the mean performance of students taught by mentored and non-mentored teachers. Therefore the null hypothesis of no significant difference was rejected for the alternative hypothesis of significant difference.

\section{Discussion of Results}

The result of this study with regard to research question 1 shows that mentoring of newly qualified and employed teachers (NQETs) enhances the new teacher's knowledge of subject matter (KSM) hence, from the observation of the MTs in the classroom teaching, all the items (1-12) observed have mean scores greater than 3.50 used as rating for positive result. The finding is in agreement with the assertion of Pollard that mentoring of newly qualified and employed teachers through, discussion, modeling and coaching enhances development of knowledge of subject matter, concrete skills to teach, observe, assess and reflect [7]. The result of this study is also in agreement with the findings of Lindgren [6]. In his study on professional support to novice, teachers by mentoring, found that mentoring made the new teachers to become more of professional in their practices which indicated personal and professional growth. The finding is also in agreement with the work of Ingersol and Kalik; they reviewed 10 empirical work on teacher mentoring [4]. These works provided empirical evidence for the claim that giving assistance to new teachers through mentoring has positive impact on teachers' knowledge and retention.

With regard to research question 2, data analysis revealed that mean score performance of mentored teachers on some selected classroom competences and reflective ability are greater than 2.50 while on the part of non-mentored teachers, mean score on all the items are less than 2.50 used as the minimum mean rating for positive responses. This implies that mentored teachers have professionally improved on the selected classroom competences while the nonmentored teachers are professionally less developed on the selected classroom competences. This finding is in agreement with the work of Lindgren titled novice teachers experiences of work, planning and mentoring during a year [5]. He noted that mentoring develop professional competences and skills and also increase their self confidence and enhances reflective ability.

With regard to hypothesis 1 , the result of the study showed that the calculated t-value (8.68) at 0.05 level of significance is greater than value of table $t$ (2.10) , that is; $(8,68>2.10)$ (See table 4). The implication is that there is significant difference in the mean score performance of mentored and nonmentored teachers on the knowledge of subject matter. The finding is in agreement with the work of
Pollard who noted that teacher mentoring increases teachers knowledge and retention [7].

With regards to hypothesis 2, the result of the study revealed that there is significant difference between the mean performance of MTs and NMTs on the development of their classroom competences and reflective ability $(11.51>2.10)$ at 0.05 level of significance. The finding is in agreement with the assertion of Avarado [1]. He noted that a good mentoring process support the development of professional skills and encourages reflection.

With regards to hypothesis 3, the result revealed that the value of t-calculated (13.81) is greater than the value of the critical $-t$ (1.67) at 0.05 level of significance. The implication is that students taught by mentored teachers performed better than students taught by no-mentored teachers in Basic science achievement test. This is a confirmation that when newly employed teachers are mentored by experienced teachers in the same professional status, they gain a lot, both knowledge of the subject matter, professional competence and skill reflective abilities and more.

They apply all that they have learnt in teaching their students and students evidently perform better in achievement tests.

\section{Conclusion}

The study investigated the effect of teacher mentoring on teachers' professional development in Owerri Educational zone. The result of the study revealed that NQETs who were mentored, performed better in classroom teaching than NQETs who were non-mentored both in the knowledge of subject matter and classroom competences. Also, students taught by mentored teachers performed better than those taught by non-mentored teachers.

\section{Recommendations}

Based on the findings of the study, the following recommendations were made.

1. Newly qualified and employed teachers (NQETs) should be assigned to teacher mentors of the same professional status (in the same institution) who will give them support and guidance required on their new profession.

2. That the State School Management Board (SEMB) and State Universal Basic Education Board, should organize orientation on appropriate strategies of teacher mentoring for more experienced serving teachers.

3. That teacher training institutions should use mentoring to improve teachers' professional practice and growth in teacher education. 


\section{References}

[1] Avarado A (2006): New Direction in Teacher Education; Emerging Strategies from the teacher for a new initiative. Paper presented at the American Educational Research Association (AERA), April, $7-11$ in San Francisco.

[2] Duru V.N. (2011): Curriculum studies; Concepts, Development and Implementation. Owerri, AVAN Global Publications.

[3] Furlong, J; Wilkin, M, Maynard, $\mathrm{T}$ and Miles, S. (1994): The Active Mentoring Programme, Cambridge: George Pearson.

[4] Ingersol, R. and Kralik, J.M. (2004): The impact of mentoring on teacher retention; what research says. Education Commission of the state (ECS), Research review, Broadway: Denver Co. www.ecs.org

[5] Lindgren, U. (2003): Novice teachers experiences of work planning and mentoring during a year. Umea University, Dept. of Swedish and Social Sciences.

[6] Lindgren, U. (2004): Professional support to novice teachers by mentoring. Umea University, Dept. of Swedish and Social Sciences.

[7] Pollard, A. (2005): Reflective teaching ( $2^{\text {nd }}$ Ed.). Evidence-informed professional practice, London Continuum Publications. 